\title{
The Use of Intermediate Channels as a Strategy to Minimize Imposition in Intercultural English-speaking Contexts - Implications for Modifications of English Linguistic Politeness Theories
}

\author{
Pham Thi Hong Nhung \\ Dept. of English, Hue University of Foreign Languages \\ 57 Nguyen Khoa Chiem, Hue city, Vietnam \\ Tel: 84 -354- 828421Ｅ-mail: nhungpham76@yahoo.com
}

Received: June 10, 2014 Accepted: July 18, $2014 \quad$ Published: September 16, 2014

doi:10.5296/jsel.v2i2.6317 URL: http://dx.doi.org/10.5296/jsel.v2i2.6317

\begin{abstract}
The paper reports an interesting data corpus of the Vietnamese using intermediate channels to reduce imposition in English-speaking intercultural workplace contexts. It draws on a collection of 71 imposition-related incidents in which the Vietnamese working with Westerners (Anglo-culturals) reported situations of their (not) undertaking act of imposition on their Western counterparts. The data analysis reveals 5 major types of intermediate channel deliberately employed by the Vietnamese to reduce the degree of imposition of their acts, especially those costly to their Anglo-cultural addressee. This shown that in English-speaking intercultural contexts, a change in the form of language (i.e., linguistic strategy) is not necessarily the only means employed to reduce the degree of imposition. This suggests modifications to English linguistic politeness theories, especially that by Brown and Levinson's $(1978,1987)$.
\end{abstract}

Keywords: imposition, politeness, intercultural communication, intermediate channel 


\section{Introduction}

\subsection{Imposition and Linguistic Politeness}

In everyday usage, imposition is closely associated with concepts like demand, burden, weight, hardship, intrusion, nuisance and enforcement. The term "imposition" is defined in the Oxford English Dictionary as "the action of putting, placing, or laying [a burden, duty, charge, or task] on" (p.131), while the verb "to impose" is described as "to lay on, or to set on", and "to put, place, or apply authoritatively" (p. 130). In the research literature on language and communication, "imposition" is commonly referred to as "the act of putting a burden on" (Goldschmidt, 1996, p. 244) or the burden placed on the addressee by the addresser (Bargiela-Chiappini \& Harris, 2006).

The most influential view of imposition and its role in politeness behaviour is systematically developed in Brown and Levinson's face-centred model of politeness in the aspect of negative face, which refers to "the want of every 'competent adult member' that his actions be unimpeded by others" (Brown \& Levinson, 1987, p. 62). Non-imposition is seen as a derivative politeness of negative face. In order to be polite people try to alter their language use to minimise the degree of imposition that their verbal acts cause to others, and when possible avoid imposing on others (i.e., try not the make the other feel that they are imposed on). In dealing with negative politeness Brown and Levinson (1987) focus only on linguistic politeness. They pointed out that negative politeness with redressive actions which are taken to change the linguistic forms is realized to reduce the potential imposition. In other words, to be polite in the context of acts of imposition (i.e., to attend to the hearer's want of freedom of action), a redressive action which primarily involves a change in the form of language use is adopted in order to compensate for and/or reduce imposition. For instance, when expressing one's wish to borrow something from another person, one tends to say: "Could you possibly lend me your book?", instead of "Lend me your book". The change in the form of language use from an imperative: "Lend me your book" to a question about the hearer's ability (i.e., "I am asking whether you can have the ability to lend me your book") makes one's request to borrow the other's book "softer" - less imposing, and so much politer. From this perspective Brown and Levinson suggest the following strategies for linguistic politeness behavior.

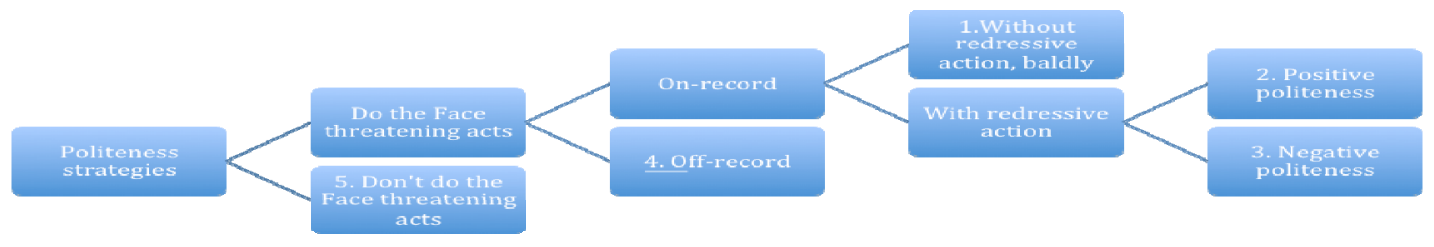

Figure 1. Politeness strategies (Brown \& Levinson, 1987, p. 69)

In Figure 1, Strategy 1 (i.e., without redressive action, baldly) can be illustrated when people 
make orders or requests in the form of imperatives, for instance: "Turn down the music", instead of "Could you turn the music down a bit, please?". Strategy 4 (i.e., the off record strategy) is employed when people use hints, irony or metaphors to imply their want(s) to the addressee. For example: "It is a bit hot in here" can be used to imply a request like: "Could you open the window?". Strategy 5 (don't do the face-threatening act) is used when people do not express their wish in any form. For instance, people remain silent and do not show any unusual non-verbal expressions in situations where they want to express a request or a refusal.

Strategy 3 (i.e., negative politeness) is employed when the addresser explicitly expresses his/her attendance to and respect for the addressee's desire for freedom in action. This strategy performs the function of minimizing the particular imposition that results from an utterance. This is seen in situations where people do verbalize their wishes / thoughts and show that they are sensitive towards the other's want of being un-impinged on, by employing linguistic expressions which prevent the other from thinking that $s /$ he is being imposed on. A typical example of negative politeness is the employment of conventional indirectness in expressing requests, as seen in questions concerning the addressee's ability: "Could you open the door?", instead of an order (i.e., Strategy 1): "(You) open the door". As Searle (1975, 1996) maintains, the chief motivation for using indirect forms is politeness. Giving advice in the form of conditional sentences is another example. For instance, by saying, "if I were you I would give up smoking", the addresser advises the addressee to stop smoking, but at the same time shows the addressee that the addressee is not the addresser, and so the addressee does not have to give up smoking if the addressee does not want to. By not saying "you must stop smoking", but rather putting oneself in the position of the other and expressing a conditional proposition, the speaker shows respect for the other's wish for freedom in action, and so is polite. Strategy 3 is therefore characterized by self-effacement, formality and restraint, centring on the addressee's want to be unimpeded (Brown \& Levinson, 1987, p. 70).

As demonstrated in Figure 2, in these four strategies the addressee's desire for being free from imposition is increasingly satisfied as we move from Strategy 1 (without redressive action) $\rightarrow$ Strategy 3 (negative politeness) $\rightarrow$ Strategy 4 (hints, irony, metaphor) to $\rightarrow$ Strategy 5 (not doing the act at all):

\author{
Negative Politeness Strategies \\ Strategy 1 . Turn the light on! \\ Strategy 3. Could you (please) turn the light on? \\ Strategy 4. It is a bit dark in here. \\ Strategy 5. (saying nothing)
}

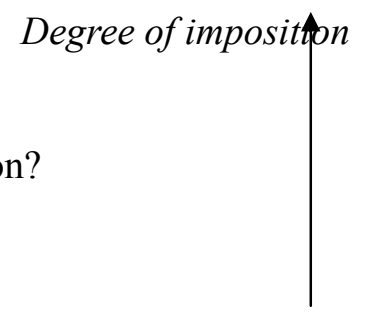

Figure 2. The degree of imposition changes in accordance with politeness strategies

Seen from another perspective, according to Brown and Levinson the primary force for 
people's linguistic politeness behaviour is their respect for the wish of non-imposition, i.e., people are polite in order not to threaten others' want for autonomy and freedom of action. Negative politeness is oriented mainly toward partially satisfying (redressing) the addressee's basic want to maintain claims of territory and self-determination. Negative politeness, therefore, is essentially avoidance-based in the sense that the realizations of negative-politeness strategies consist of assurances that the speaker recognises and respects the addressee's desire for autonomy and will not (or will only minimally) interfere with the addressee's freedom of action. As emphasized by Brown and Levinson, their model of politeness reflects Durkheim's (1915) view that "one dare not violate it nor infringe its bound, while at the same time the greatest good is in communication with others" (p. 299).

Being centred on the notion of non-imposition as politeness, since its introduction Brown and Levinson's $(1978,1987)$ work has become the benchmark in the field, despite various controversies and criticisms regarding its validity (Eelen, 2001; Pham, 2007, 2014a, 2014b; Watts, 2003; Xi, 2003).

\subsection{Acts Causing Imposition}

Based on the potential imposition that an act may incur on the part of the addressee, Brown and Levinson $(1978,1987)$, as well as many others working in their framework (e.g., Barnlund \& Araki, 1985; Berman \& Kasper, 1993; Henderson, 1996; Holtgraves \& Yang, 1992; Suszczynska, 1999; Yeung, 1997), have maintained that acts which primarily threaten the addressee's want for autonomy and freedom of action include:

(1) Those acts that assert some future act A of the addressee, and in so doing put some pressure on the addressee to do (or refrain from doing) the act A:

(a) orders and requests (the speaker indicates that $\mathrm{s} / \mathrm{he}$ wants the addressee to do, or refrain from doing, some act A);

(b) suggestions, advice (the speaker indicates that $\mathrm{s} /$ he thinks the addressee should do some act A);

(c) remindings (the speaker indicates that the addressee should remember to do some act A);

(d) threats, warnings, dares (the speaker indicates that he - or someone, or something - will instigate sanctions against the addressee unless the addressee does act A);

(2) Those acts that predicate some positive future act of the speaker toward the addressee, and in so doing put some pressure on the addressee to accept or reject them and possibly to incur a debt:

(a) offers (the speaker indicates that they want the addressee to commit themselves to whether or not they want the speaker to do some act for the addressee, with the addressee thereby incurring a possible debt);

(b) promises (the speaker commits to a future act for the addressee's benefit). 
(3) Those acts that assert some desire of A toward the addressee or the addressee's goods, giving the addressee reason to think that they may have to take action to protect the object of the speaker's desire, or give it to the speaker:

(a) compliments, expressions of envy or admiration (the speaker indicates that they like or would like something of the addressee's);

(b) expressions of strong (negative) emotions towards the addressee, for example, hatred, anger (the speaker indicates possible motivation for harming the addressee or the addressee's goods) (Brown \& Levinson, 1987, p.65-66).

In other words, according to Brown and Levinson (1987), both acts that are costly to the hearer (e.g., request, suggestion, order) and acts that are perceivably beneficial to the hearer (e.g., offer, promise) can potentially incur an imposition on the part of the addressee. Since Brown and Levinson $(1978,1987)$ take the perspective that linguistic politeness is centred on the individual want for freedom in action and claim of territory (Matsumoto, 1989), in their model the group of acts that can potentially make people feel imposed upon is broadly extended.

\subsection{Reducing Imposition}

According to Brown and Levinson (1987), the degree of imposition of an act (i.e., how people select a strategy in order to reduce or not to reduce the perceived imposition level) varies according to three main factors: power difference $(P)$, social difference $(D)$ between the speaker and the addressee, and the weight ranking of the act itself (R) (e.g., a question about time incurs less imposition than a request for money).

In terms of the ranking of the act (R), Brown and Levinson note that the weight of a specific act may vary across cultures: the same act may be perceived to incur different levels of imposition in different cultures. They also maintain that imposition is ranked in proportion to the expenditure of resources, including time and effort. Given that one's immediate mood and physical condition could impact heavily on how one may perceive the degree of imposition from what others say (Ervin-Tripp, 1976, p. 50-63), in evaluating contexts in which there are different degrees of imposition, Goldschmidt (1996) found that family privacy is rated very high by the American participants of the study. The participants also rated situations which involve a great deal of time and effort at a high degree of imposition. Sensitivity to the degree of imposition or intrusiveness in requesting is often learned by school age, when children become aware of what might be difficult or disruptive from the hearer's perspective, and hence are able to vary their language use accordingly (Ervin-Tripp \& Gordon, 1986).

Brown and Levinson claim that when non-imposition is maximised, politeness increases accordingly, and as imposition increases, politeness reduces accordingly. They thus suggest a positive correlation between non-imposition and politeness. The interpretation of the following examples from Leech (1983) will help illustrate how people can reduce the degree of imposition in their acts, and hence increase the level of politeness.

(1) Will you have anything to eat? 
(2) Will you have something to eat?

(3) Won't you have anything to eat?

(4) Won't you have something to eat?

Leech (1983) stated that (1), (2), (3) and (4) are increasingly polite. Leech's argument of why (3) and (4) are more transparently polite than (1) and (2) goes roughly as follows. In (3) the speaker questions the addressee's denial of the speaker's assumption that the addressee will have something to eat. The message conveyed in (3) may be "I hope and expect you to have something to eat; is it really so?" (Leech, 1983, p.110): the speaker attributes polite refusal to the addressee, while still giving him / her chance to change his / her mind. (4) is even more polite than (3) because of the use of the positive polarity of something instead of anything, which refers to non-factuality. As inferred from Brown \& Levinson (1987), the imposition intensity gradually reduces from (1) to (4). Specifically, what makes (3) and (4) more polite than (1) and (2) is that by employing a negative form (i.e., "won't"), the inviter reduces the degree of imposition, and thereby shows their respect for the invitee's desire for freedom of action. The message behind "won't" is "You don't have to feel obliged to accept my invitation. Actually you can either accept or easily reject it", since "won't" makes it possible for the invitee to reject the invitation. Brown and Levinson argue that by going on record with negative politeness, the inviter can pay respect and deference to the addressee, and can thereby lessen or avoid incurring a future debt; the inviter can also maintain social distance, and so avoid the threat of advancing familiarity towards the invitee; the inviter can give a real "out" to the invitee by making it clear that the inviter does not really expect the invitee to say "Yes" unless the invitee wants to, thereby minimizing the mutual face loss incurred if the invitee has to say "No"; and the inviter can give conventional "outs" to the invitee, as opposed to real "outs" - that is, pretend to offer an escape route without really doing so, thereby indicating that the inviter has the other person's face wants in mind (Brown \& Levinson, 1987, p. 72). Scollon and Scollon (1995) comment that it is this sensitivity towards the connection between non-imposition and politeness that makes offers like: "Wouldn't you like to drink something?", or "It would be nice to have tea together, but I am sure you are very busy" perceived to minimise their imposition intensity, and so are polite.

Furthermore, a theme shared by both Leech and Brown \& Levinson is their preference for optionality, that is, the importance of giving options with the emphasis that the decision on whether to accept the invitation or not must be in the hands of the invitee, that is, "you can say yes if you like but you can also say no easily". By providing an avenue for the invitee to refuse the offer, the inviter reduces the imposition intensity, shows their reluctance to impinge on the invitee, and thereby satisfies to some extent the invitee's want to be left unimpeded. This common emphasis on optionality and non-imposition links Leech's and Brown \& Levinson's arguments closely with Lakoff's (1973, 1975, 1990), since non-imposition and optionality are the two main rules in Lakoff's politeness theory (i.e., 1. Don't impose and 2. Give options). According to this view, optionality is an essential factor in reducing the degree of imposition, and thereby in increasing politeness.

Despite the massive body on linguistic politeness and on strategies to reduce imposition that 
cause imposition as selectively reviewed above, there is little research on means other than linguistic strategies that may be employed to soften imposition, especially in intercultural communication contexts. This paper therefore, reports on an interesting corpus of data where the Vietnamese involved in English-speaking intercultural workplaces employ intermediate channels as a means to soften imposition in their communication with Western counterparts.

\section{Research Methodology}

\subsection{Participants}

The participants of the present research are 24 Vietnamese speakers of English who work full-time with Anglo native speakers of English (specifically British, Americans and Australians) in various offices of non-government-organizations' (NGO) foreign-funded projects in areas of Central Vietnam. The participants comprise 15 males and 9 females, aged from 28 to 46 . They had at least 5 years of work experience at the time of the study. They are in different positions in their jobs, ranging from secretary, officer and consultant to programme / project coordinator or director. They work with native speakers of English, most of whom come from English-speaking countries like America, Australia and Britain. As a requirement of their jobs, the participants must be able to use English to communicate competently.

\subsection{Research Instruments}

A diary-type record sheet was chosen as an instrument to collect data. This was done by means of self-reflective diary-type records of naturally occurring incidents where Vietnamese - Westerner (Anglo-culturals) interactions are involved. Self-reflective diary-type records have been employed, validated and recommended in varied research on politeness in intercultural communication (e.g., House, 1989, 1996, 2000; Spencer-Oatey, 2000, 2002, Spencer \& Xing, 2003). The use of self-reflective reports of noticeable incidents in this research was, therefore, meant to give the Vietnamese participants opportunities to express their own understanding, explanation and interpretation about their politeness behaviour in interaction with Anglo-culturals, which, in its turn, provided better insights into their behaviour.

In the search for rich data, each participant was asked to complete at least two record sheets. One type of sheet was to record the most noticeable event with a particularly negative effect, explicitly explained as interactions with Anglo-cultural native speakers of English that made him / her feel particularly annoyed, insulted, embarrassed and/or humiliated. The other was to record the most noticeable event with a particularly positive effect, explicitly explained as interactions with Anglo-cultural native speaker(s) of English that made him / her feel particularly happy, proud and/or satisfied. Each record sheet comprised 2 sections: (1) information about the participant and (2) information about the recorded event.

The descriptive information section provided details of the participants of the present study, including their gender, age, the length of their employment, and the frequency of working with people from English-speaking cultures. 
The main section of the record sheet contained 5 subsections, including:

1) The setting where the participants were asked to give information about the place and the time of the occurrence;

2) Information about the other people involved (specifically gender, age, nationality, the relationship with the participant, the length of acquaintance, and the intensity of the relationship according to the participants' subjective evaluation);

3) The report of the occurrence;

4) The participants' immediate reactions and feelings and

5) The reasons for the participants' reactions and feelings. For some sections, where a clarification of the relevant information was needed, some examples and/or prompts were provided. For example, for the section "The relationship with you", prompts such as "colleague" and "subordinates" were given.

The present study also used information from record sheets as a guide for the follow-up semi-structured interviews, which were designed to understand in more depth the incidents where the participants as Vietnamese working in intercultural contexts reported their act of imposing on their Western counterparts.

After the data collection process finished, 135 incidents were collected via the record sheet instrument, and 69 more were elicited during the follow-up interviews, which resulted in a total of 204 incidents reported in Vietnamese. Of these, 3 did not involve direct interactions with Anglo-culturals, but rather the participants' feelings about their Anglo-cultural counterparts' general behaviour, and so these three incidents were discarded. This left 201 incidents, 71 of which reported instances where the Vietnamese described how their act of (not) undertaking an imposition on their Western counterparts involves an intermediate channel in intercultural contexts. Although the intermediate channel were not structured as an independent variable of the study, the involvement of intermediate channels as a means to reduce imposition in these 71 imposition-related incidents has provided an interesting corpus of data for analysis.

\section{Findings and Interpretations}

An analysis of the corpus of 71 imposition-related incidents has shown that 5 major types of intermediate channel were used deliberately by the Vietnamese to reduce the degree of imposition of their acts, especially those costly to their Anglo-cultural addressee. 
Vietnamese Speaker of EFL

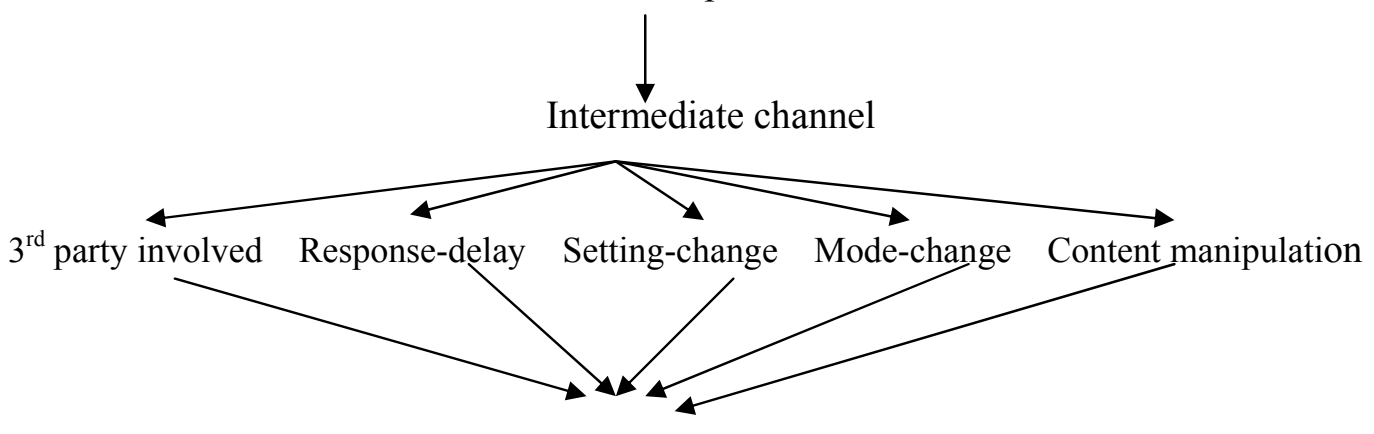

Western Addressees

Figure 3. Intermediate channels employed to reduce imposition

The Vietnamese use of intermediate channels is summarized in Figure 3. The first type of intermediate channel is Third party involvement, referring to the phenomenon that the Vietnamese involved a third party person / people when undertaking acts of imposing, including:

a) citing other people's situations, to imply that the imposition being incurred is not an exception;

b) asking others (often Vietnamese) to undertake the act (e.g., request or complaint), i.e., to deliver imposition on one's behalf and

c) relying on a third party (often Vietnamese) to avoid performing imposition acts on Westerners.

Examples for each type of Third party involvement are presented below.

Among these 3 types of Third Party Involvement, a) and b) are often used together with Strategy 3 (politeness strategy), and c) is often used in situations where non-imposition (Strategy 5) is adopted.

In terms of Third Party Involvement type a) - citing other people's situations, to imply that the imposition being incurred is not an exception - the incident described below can be used as an example.

[1] (1)

I used to be intimate with my former boss but because of his inflexible viewpoints our good relationships did not last long. Once on the way to a village for a fieldtrip, while we [I, my Anglo-cultural boss and the driver] were talking about woman and child things, I suggested that he should get married. He was my older brother's age, 42. In Vietnam men at that age will worry their parents if they are not married yet. Generally, I was suggesting in a friendly way because I was concerned about him, who I considered my brother. I said my brother was of his age but already had two children. He said he was too independent to get married. I asked him why he did not try because if he did not try how he could know he was not suitable 
for family life. However, he did not seem to take my advice seriously [...] he just laughed $[\ldots]$.

As seen from the incident described above, the Vietnamese insisted on the Anglo-cultural's acceptance of his suggestion that he [the Anglo-cultural] should get married, which was meant to be understood as an expression of care, concern, closeness, and hence politeness. The case of his brother was even quoted by the subject in order to persuade the Anglo-cultural with whom he was interacting: "I said my brother was of his age but already had two children". However, from the Anglo-cultural perspective, such an act is probably viewed as impolite in the sense that it directly interferes with one's wish to have full freedom in one's personal life (Brown \& Levinson, 1978, 1987), and so the Anglo-cultural in this situation might have taken his Vietnamese colleague's comment as a criticism.

Third party involvement type b) - asking others (often Vietnamese) to undertake the act of imposition on the Anglo-cultural on one's behalf - is illustrated in situations where the Vietnamese staff member decided not to make a request himself to his Anglo-cultural supervisor; but rather asked the secretary of their organization to make a request on his behalf.

As far as Third Party Involvement type c) - relying on a third party (often Vietnamese) to avoid performing imposition acts on Anglo-culturals) - is concerned, the situation portrayed below is a typical example.

Our office used to have a fund for organizing farewell parties and activities of similar kinds such as buying presents for staff members' weddings, souvenirs on the occasion of staff members' parents' death, and so on. However, at this time, that fund was running out. Just 2 weeks ago, in a meeting with the whole staff members, the [Anglo-cultural] chief supervisor said that they could not maintain the fund due to the current shortage in the budget of the organization. We [the Vietnamese staff members] were all frustrated about that decision but none of us said anything. He [the Anglo-cultural chief supervisor] was the decision-maker anyway. [...] It is not just about the funding: it is also about the concern for the staff members on their important occasions, especially for those who are leaving the project [...]. In my meeting with him [the Anglo-cultural chief supervisor] [for monthly report] last week I could have told him what I thought and suggested that he should reconsider his decision on the funding, because I am head of trade union in the programme. However, he was our boss in any case and here [in the programme] we [the Vietnamese staff members] often remind one another of two unwritten rules: rule number 1: the boss is always right and rule number 2: if the boss is not right, see rule number 1 . Additionally, I was not very close to him and did not know him well enough to be able to anticipate his reactions, so finally I left his office without making the suggestion [that he should reconsider his decision on the funding]. [...] Later on we [the Vietnamese staff members] agreed to establish a fund ourselves in order to replace the previous official fund of the programme. We [the Vietnamese staff members] all contribute to it so that we still can organize similar activities without depending on the Anglo-cultural budget. [...] Although we could find a way to solve this problem among 
ourselves [the Vietnamese staff member] I still feel that Anglo-culturals are often inconsiderate to others, and inflexible at work.

In the encounter described above, Power Difference is the most influential element that directed the Vietnamese in the lower position not to execute the imposition act, which is potentially costly to the Anglo-cultural addressee. His awareness of the status difference (i.e., Power Difference) between himself and his Anglo-cultural colleague prevented him from making a request to maintain the funding on behalf of other Vietnamese staff members in the programme. Instead they decided to find an alternative way to keep the funding going, even when this decision was costly to them. The Vietnamese staff member was fully aware that in his position he could request to maintain the fund for social affairs of the organization: "In my meeting with him [the Anglo-cultural chief supervisor] [for the monthly report] last week I could have told him what I thought and suggested that he should reconsider his decision on the funding, because I am head of the trade union in the programme". However, in the event he did not verbalize the request in any form (Strategy 5). In addition to his adoption of Strategy 5, he suggested to his Vietnamese colleagues that they contribute to the fund themselves as a way of avoiding performing an imposition act on the Anglo-cultural chief supervisor of the organization: "Later on we [the Vietnamese staff members] agreed to establish a fund ourselves in order to replace the previous official fund of the programme. We [the Vietnamese staff members] all contribute to it so that we still can organize similar activities without depending on the Anglo-cultural budget”.

The second type of intermediate channel is Response Delay, which refers to the phenomenon that the Vietnamese tend not to undertake the act if it is costly to addressee at the time it is meant to be done, although they would eventually perform it. This act of delaying executing an imposition on Anglo-culturals is often due to the Vietnamese consideration for the immediate negative effect of the potential act. For instance, as seen later in [1] (4), when communicating with her Anglo-cultural counterpart, the Vietnamese in the position of manager of the organization decided at once that she would refuse his request to move their meeting forward to several days later than scheduled. However, she did not express her refusal in her face-to-face interaction with the Anglo-cultural; but rather: "What I did was I told him [Mr. J] that I needed some time to think before I could give him the answer [tell him my decision]". Although she would eventually inform the Anglo-cultural that she and her staff members could not accept his request, the fact that she did not refuse at once, but chose to refuse at a time that she thought was more appropriate, shows that her act of delaying giving a response to the Anglo-cultural's request was strategically and deliberately performed.

The third type of intermediate channel is the Vietnamese deliberate Change of the Setting in which the imposition would be undertaken. For instance, when a Vietnamese staff member wanted to take his annual leave at short notice, he invited his Anglo-cultural boss to drink beer in a pub, where he would make the request over the drink in the hope that the informal atmosphere outside the workplace would make his request "softer".

The fourth intermediate channel used is the deliberate Change of Mode of Communication, 
which refers to the Vietnamese tendency of switching from performing the act in face-to-face speaking contexts to undertaking the act via other communication channels such as email or telephone. As also seen in [1] (4), the Vietnamese manager chose to deliver her refusal not in a face-to-face context, but rather via email. Similarly, the Vietnamese also tend to rely on the telephone as a means of reducing the possible intensity (i.e., to reduce the potential degree of imposition) that they may cause as a result of their performance of imposition acts.

The last type of intermediate channel is Content manipulation, referring to the phenomenon that the Vietnamese deliberately modify the communicative content, including telling untruths, when they think that it can help reduce the perceived degree of imposition of their act. For example, a Vietnamese reports that in refusing her Anglo-cultural female colleague's invitation to her birthday party, the Vietnamese chose to give the Anglo-cultural colleague a present and said: "I would love to go, but my mom is unwell so I can't". However, her mother was in fact, not ill, but she thought: "it [the made-up excuse] would make the refusal sound politer $[\ldots]$ and easier to be sympathetic with."

\subsection{The Operation of Intermediate Channels}

These five types of intermediate channel are not necessarily used separately. More than one type can be used in a situation, in the belief that they can reduce imposition and increase the possibility that the imposition would be accepted.

Table 1. The allocation of intermediate channels within the Vietnamese acts of imposition

\begin{tabular}{|l|l|l|l|l|l|l|}
\hline $\begin{array}{l}\text { Intermediate } \\
\text { channel types }\end{array}$ & $\begin{array}{l}\text { Third party } \\
\text { involvement }\end{array}$ & $\begin{array}{l}\text { Response } \\
\text { delay }\end{array}$ & $\begin{array}{l}\text { Channel } \\
\text { change }\end{array}$ & $\begin{array}{l}\text { Setting } \\
\text { change }\end{array}$ & $\begin{array}{l}\text { Content } \\
\text { manipulation }\end{array}$ & Total \\
\hline Strategy 1 & $3(\mathrm{a})$ & 0 & 0 & 0 & 0 & 3 \\
\hline Strategy 3 & $\begin{array}{l}9 \quad(\mathrm{a}), \quad 10 \\
(\mathrm{~b}), 1(\mathrm{c})\end{array}$ & 17 & 9 & 7 & 8 & 61 \\
\hline Strategy 4 & 0 & 0 & 0 & 0 & 0 & 0 \\
\hline Strategy 5 & $5(\mathrm{c})$ & 0 & 0 & 0 & 2 & 7 \\
\hline Total & 28 & 17 & 9 & 7 & 10 & 71 \\
\hline
\end{tabular}

As shown in Table 1, intermediate channels are used most frequently in situations where Strategy 3 is used: 61 in the total of 71 occurrences. This figure of 61 is even more significant, given that among the whole set of imposition-related data, the total number of incidents in which Strategy 3 is used (i.e., imposition is verbalized) is 60,50 of which is associated with addressee-costly acts.

Brown and Levinson (1987) maintain that being direct and "straight to the point" is seen as a negative politeness strategy. Their rationale is that "intuition tells one that there is an element 
in formal politeness that sometimes directs one to minimise the imposition by coming rapidly to the point, avoiding the further imposition of prolixity and obscurity" (p. 130). Lakoff (1973) even suggests that this is the most important feature of politeness. The significant operation of the intermediate channels found in the present research has shown that this is not necessarily true in the case of the Vietnamese participants in the present study. The use of the intermediate channel is directed in Confucian-based orientation towards harmony and balance. However, it is very under-represented in the literature on intercultural communication involving people from Asian Confucian cultures. The considerable Vietnamese use of these intermediate channels puts Vietnamese communication in intercultural contexts in direct opposition with the Hebrew concept of dugri - directness or "straight talk" (see also Katriel (1986), Maschler (2001), and Zupnik (2000)).

With respect to intermediate channel types, Third Party Involvement is the most frequent in the data, with 28 in the total of 71 occurrences of intermediate channels. In these 28 occurrences, comparing one's act (e.g., request) with other people (type a), and using others to deliver the messages (type b), are the most popular strategies in the Vietnamese realization of addressee-costly acts ( 9 and 10 times respectively): relying / imposing on a third Vietnamese party (type c) is most popular in situations where the Vietnamese decided not to impose on Anglo-culturals. An example of third party involvement-type (a) can be seen in a situation where the Vietnamese in a junior position makes a request to his Anglo-cultural boss. He told his boss that he was not the only one to request a new computer, and some other colleagues had a new computer, even when the previous computer was in better condition than his. The interpretation of the Vietnamese involved in the interaction, in referring to other people when making the request, shows that by so doing he could reduce the tense atmosphere which had already been created by the request. Nevertheless, whether this behaviour is perceived in the same way (to reduce imposition, i.e., to be polite) by the Anglo-cultural addressee is another matter.

The following example illustrates the use of third party involvement-type b:

Two years ago when I was still in charge of suburb areas where the irrigation and drainage project was implemented, I had to travel frequently by car to rural areas for field trips. On those occasions I was often seriously carsick and exhausted after every fieldtrip. Many times I was going to tell my [Anglo-cultural] supervisor to ask for a work transfer since physically I was not suitable for frequent fieldtrips by cars. Nevertheless, it was not easy since he was boss and we were not close [...]. When I found that I could not cope with car trips any more, I talked to L, my [Vietnamese] colleague, who was in the team working with me and who understood well my situation. I asked him to talk to my supervisor to help him understand my situation [...] because he and my supervisor seemed to have an intimate relationship. [...] Nevertheless, several days later I was called to see him [my supervisor] in the office and he asked me about my situation and I did make the request for a work transfer. [I asked him if I could get another post in the project]. Although he was sympathetic, he seemed unhappy about me asking $\mathrm{L}$ to tell him about my situation. [...] He said that if I had any problem I 
should be the first person who let him know in the first place not anybody else. I felt embarrassed.

The interview with the Vietnamese involved in [1] (3) suggests that she believed that a close relationship with the boss would make it more likely that her colleague would have the request accepted by the Anglo-cultural boss; and that having her trouble talked about by somebody else seemed to be more objective and convincing, and that the request would also sound "softer" and "more gentle". To her, informing the Anglo-cultural boss of her situation in advance is a way to prepare him for her situation before she herself made the request to him, that is to anticipate her future request. In addition, feedback from her colleague about the Anglo-cultural supervisor's reactions towards her situation would help her made the right decision: whether to make the request officially or not. In her view, even if she sensed that her request was not approved, she still had "a way out", that is she could still keep her current job since it was not she who made the request anyway. When asked whether she thought of the cost that her colleague might have to pay (e.g., a feeling of discomfort or bad impression / reaction from the Anglo-cultural boss) when he made the request for her, the subject said that in her view, it would be unlikely to cost her colleague anything, since he did not make the request for his own sake but on behalf of someone else. In her belief, this would help him to earn more credit in the eyes of the Anglo-cultural boss (i.e., he was caring about his colleagues), rather than incurring a cost to him. Similarly, in another situation, the Vietnamese employee who was going to submit her resignation let her plan be unofficially transmitted in advance to the Anglo-cultural boss by his secretary before she made the request officially, thinking that by so doing she would be able to prepare the boss, and thereby avoid a potentially sudden negative reaction, as well as maintain the immediate emotional quality of the relationship. The involvement of the third party-type b) (i.e., to deliver the addressee-costly messages) for the purpose of reducing imposition is inconsistent with the above result - that in the presence of a third person Vietnamese tend not to impose on the Anglo-cultural they are interacting with, especially when they are in a lower position. However, these related incidents show that the Vietnamese tend to involve a third party in the process of delivering the imposition when they focus more on the possibility of the Anglo-cultural acceptance of their imposition (i.e., the final effect of the act). In contrast, when the concern for the outsider's potentially negative judgment on either oneself and/or one's Anglo-cultural interactant is greater, the degree of imposition is minimised in the presence of a third person / people.

As shown in Table 1, besides third party involvement, response delay is also one of the intermediate means that the Vietnamese use to reduce imposition, especially in undertaking addressee-costly acts. A close examination of situations in which the Vietnamese intentionally delayed performing hearer-costly acts indicates that this means is often used together with setting change and/or channel change:

According to our plan, Mr. J [a staff member of the World Vision partnership office] would visit our office [the World Vision office in Hue] that week. However, 2 days before the 
scheduled meeting, I got an email from him [Mr. J] in which he said for some reasons he would prefer to visit our office and work with us several days later than the original schedule said. I replied to him, saying that it would be fine although it is not always easy to re-schedule your work plan and work re-scheduling would affect not only me but also other supporting staff member in the office. However, one day before the re-scheduled meeting day Mr. J suddenly turned up in our office, saying that there was an emergency and so Mr. J would meet the staff members of the World Vision office in A-Luoi (a remote mountainous area to the north of Hue city] first and suggested that we [he and I and the staff member of world vision office in Hue] should meet on the first two days in the following week. I felt my role was not respected. As manager of the World Vision office, I was not in a lower position than him and not his supporting staff member. He should not ask us to change our work plan capriciously because it is not fair. However, normally I do not refuse directly [in face-to-face communication], especially when they [Anglo-culturals] are angry or they are in bad mood, because I think my refusal can cause some bad effect even though in my position [manager] I have the right to do so directly. What I did was I told him [Mr. J] that I needed some time to think before I could give him the answer [tell him my decision] and later I emailed him saying that we regretted that we could not re-schedule our plan as he wished. I also told him that we could only meet the week after the following week. Later on I heard about his complaint from my direct supervisor in Hanoi that the world vision staff members of Hue were not cooperative. They [Anglo-culturals] should understand that we [the Vietnamese] have our own work principles and they must respect them.

The interpretation of the Vietnamese involved in the situation above shows that her reason for delaying making a direct refusal is that she does not want her refusal to cause negative effects in face-to-face interaction ("especially when they [Anglo-culturals] are angry or they are in bad mood or when I think my refusal can cause some bad effect"). The interview with her shows that by not giving an immediate answer about her decision whether she could meet with Mr. $\mathrm{J}$ in the following week, and by claiming that she needed more time to think about the decision, she hoped that Mr. J would understand that it was not easy to re-schedule her work plan as he wished, and thereby prepare him for the possibility that his suggestion would not be accepted. As indicated in the incident above, delaying making the refusal is not the only intermediate means that the Vietnamese superior used in the interaction. The Vietnamese in [1] (4) also used email as a way to make the refusal easier to accept. When asked why she replied on email to perform the refusal, she said that she found it easier and politer to do it that way, since it would be less likely to cause any immediate negative reaction, in contrast to face-to-face interaction. In addition, it would make the refusal official, just like a final decision which Mr. J could not but accept.

\section{Conclusion}

While research has shown that in intercultural communication the use of intermediate channels functions to reduce the potential cost and loss of time of interactants of different cultures and geographies (Saphiere, 1996), time loss and cost do not seem to be among the most important considerations in the Vietnamese use of intermediate channels, and especially in their realization of imposition acts on their Anglo-cultural counterparts. The analysis above 
has shown that intermediate channels are used to soften the imposition being caused by the Vietnamese on their Anglo-cultural counterparts, although the use of intermediate channels is not necessarily perceived in the same way by the Anglo-culturals involved in interactions. The prevalence of the use of intermediate channels has also confirmed that these are a crucial means of Vietnamese Confucian-based strategic politeness behaviour in intercultural contexts. Evidence from the collected data has shown that in English-speaking intercultural contexts, a change in the form of language is not necessarily the only means employed to reduce the degree of imposition. This suggests modifications to English linguistic politeness theories, especially that by Brown and Levinson's $(1978,1987)$.

\section{References}

Bargiella-Chiappini, F., \& Harris, S. (2006). Politeness at work: Issues and challenges. Journal of Politeness Research, 2, 7-33.

Barnlund, D. C., \& Araki, S. (1985). Intercultural encounters: The management of compliments by Japanese and Americans. Journal of Cross-Cultural Psychology, 16(1), 9-26.

Bergman, M. L., \& Kasper, G. (1993). Perception and performance in native and nonnative apology. In G. Kasper \& S. Blum-Kulka (Eds.), Interlanguage pragmatics (pp. 82-107). New York: Oxford University Press.

Brown, P., \& Levinson, S. (1978). Universals in language usage: Politeness phenomena. In E. N. Goody (Ed.), Questions and politeness (pp. 57-324). Cambridge: Cambridge University Press.

Brown, P., \& Levinson, S. (1987). Politeness: Some universals in language usage. Cambridge: Cambridge University Press.

Durkheim, E. (1915). The elementary forms of the religious life (Trans: J. S. Swain). London: George Allen and Unwin.

Eelen, G. (2001). A critique of politeness theories. Manchester: St. Jerome Publishing.

Ervin-Trip, S. (1976). Is Sybil there? The structures of American English directives. Language in Society, 5(1), 25-66.

Ervin-Tripp, S., \& Gordon, D. (1986). The development of requests. In R. L. Schiefelbusch (Ed.), Language competence: Assessment and intervention (pp. 61-95). San Diego, CA: College Hill.

Goldschmidt, M. (1996). From the addressee's perspective: Imposition in favor-asking. In S. M. Gass \& J. Neu (Eds.), Speech acts across cultures: Challenges to communication in a second language (pp. 241-256). Berlin: Mouton de Gruyter.

Henderson, A. (1996). Compliments, compliment responses, and politeness in African-American community. In J. Arnold, R. Blake, S. Schwenter \& J. Solomon (Eds.), Sociolinguistic variation: Data, theory and analysis, selected papers from NWAV 23 at Stanford CA (pp. 195-208). California: Center for Language and Information Stanford. 
Holtgraves, T., \& Yang, J. (1990). Politeness as universal: Cross-cultural perceptions of request strategies and inferences based on their use. Journal of Personality and Social Psychology, 59, 719-729.

Holtgraves, T., \& Yang, J. (1992). Interpersonal underpinnings of request strategies: General principles and differences due to culture and gender. Journal of Personality and Social Psychology, 62, 246-256.

House, J. (1989). Politeness in English and German: The functions of 'please' and 'bitte'. In S. Blum-Kulka, J. House \& G. Kasper (Eds.), Cross-cultural pragmatics: Requests and apologies (pp. 96-123). Norwood, NJ: Ablex.

House, J. (1996). Contrastive discourse analysis and misunderstanding. the case of German and English. In M. Hellinger \& U. Ammon (Eds.), Contrastive sociolinguistics (pp. 345-361). Berlin: Mouton de Gruyter.

House, J. (2000). Understanding misunderstanding: A pragmatic discourse approach to analysing mismanaged rapport talk across cultures. In H. Spencer-Oatey (Ed.), Culturally speaking (pp. 145-164). London: Continuum.

House, J. (2004). Politeness in Germany: Politeness in Germany? In L. Hickey \& M. Stewart (Eds.), Politeness in Europe (pp. 13-28). Clevedon: Multilingual Matters Ltd.

Katriel, T. (1986). Talking straight: Dugri speech in Israeli Sabra culture. Cambridge: Cambridge University Press.

Lakoff, R. (1973). The logic of politeness, or minding you p's and q's. Chicago Linguistic Society, 9, 292-305.

Lakoff, R. (1975). Language and women's place. New York: Harper.

Lakoff, R. (1990). Talking power: The politics of language in our lives. New York: Basic.

Leech, G. (1983). Principles of pragmatics. New York: Longman.

Maschler, Y. (2001). veke'ilu haraglayim sh'xa nitka' ot bifnim kaze ('and like your feet get stuck inside like'): Hebrew kaze ('like'), ke's ilu (like'), and the decline of Israeli duhri ('direct') speech. Discourse Studies, 3(3), 295-326.

Matsumoto, Y. (1989). Politeness and conversational universals - Observations from Japanese. Multilingua, 8(2), 207-221.

Pham, T. H. N. (2014a). Strategies employed by the Vietnamese to respond to compliments and the influence of compliment receivers' perception of the compliment on their responses. International Journal of Linguistics, 6(2), 142-165. http://dx.doi.org/10.5296/ijl.v6i2.5141

Pham, T. H. N. (2014b). How do the Vietnamese lose face? Understanding the concept of face through self-reported, face loss incidents. International Journal of Language and Linguistics, 2(3), 223-231. DOI: 10.11648/j.ij11.20140203.21

Pham, T.H. N. (2007). Understanding the Vietnamese concept of face: Evidences from its 
collocational abilities. E-Journal of Foreign Language Teaching, 4(2), 257-266. DOI: http://e-flt.nus.edu.sg/archive/v4n22007.htm

Saphiere, D. M. H. (1996). Productive behaviours of global business teams. International Journal of Intercultural Relations, 20(2), 227-259.

Scollon, R., \& Schollon, W. S. (1995). Intercultural communication. Cambridge: Blackwell Publishers.

Searle, J. (1975/1996). Indirect speech acts. In A. Martinich (Ed.), The philosophy of language (pp. 168-183). Oxford: Oxford University Press.

Spencer-Oatey, H. (2000). Culturally speaking. Managing rapport through talk across cultures. London

Spencer-Oatey, H. (2002). Managing rapport in talk: Using rapport sensitive incidents to explore the motivational concerns underlying the management of relations. Journal of Pragmatics, 34, 529-545.

Spencer-Oatey, H., \& Xing, J. (2000). A problematic Chinese business visit to Britain: Issues of face. In H. Spencer-Oatey (Ed.), Culturally speaking. Managing rapport through talk across cultures. London: Continuum.

Suszczynska, M. (1999). Apologizing in English, Polish and Hungarian: Different languages, different strategies. Journal of Pragmatics, 31, 1053-1065.

Watts, R. J. (2003). Politeness. Cambridge: Cambridge University Press.

Xi, C. (2003). Book review: A critique of politeness theories by Gino Eelen (2001). Journal of Pragmatics, 35, 811-818.

Yeung, L. N. T. (1997). Polite requests in English and Chinese business correspondence in Hong Kong. Journal of Pragmatics, 27, 505-522.

Zupnik, Y.-J. (2000). Conversational interruptions in Israeli-Palestinian 'dialogue' events. Discourse Studies, 2(1), 85-110.

\section{Copyright Disclaimer}

Copyright for this article is retained by the author(s), with first publication rights granted to the journal.

This is an open-access article distributed under the terms and conditions of the Creative Commons Attribution license (http://creativecommons.org/licenses/by/3.0/). 